\title{
Tingkat Pengetahuan Peternak Sapi Terhadap Limbah yang Dihasilkan Di Desa Sidorejo Kecamatan Penajam Kabupaten Penajam Paser Utara
}

\author{
Arif Ismanto ${ }^{1}$, Yetriani ${ }^{2}$, dan Dina Lesmana ${ }^{2}$ \\ 1,2 Jurusan Peternakan, Fakultas Pertanian Universitas Mulawarman \\ 1 Email:arifismanto9@gmail.com
}

\begin{abstract}
Cattle farming in Indonesia is still concerned with livestock productivity and has not considered environmental aspects and the impact of activities on the environment. This research aimed to finding out the level of knowledge about livestock waste in Sidorejo Village, Penajam Subdistrict, Penajam Paser Utara District. Respondents of this study were 31 cattle farmers in Sidorejo Village in 2017. The sampling method at the research location was carried out by proportional random sampling. Data obtained in the form of primary data and secondary data, then analyzed using a Likert Scale. The results of the research on the level of knowledge about waste entering cattle are in the low category $96.77 \%$ and $3.23 \%$ into the medium category.
\end{abstract}

Keywords: Knowledge of farmers, Livestock Waste, Sidorejo Village

\begin{abstract}
ABSTRAK
Usaha peternakan sapi di Indonesia sampai saat ini masih mementingkan produktivitas ternak dan belum mempertimbangkan aspek lingkungan dan dampak kegiatan terhadap lingkungan. Tujuan penelitian ini adalah untuk mengetahui tingkat pengetahuan peternak terhadap limbah peternakan sapi di Desa Sidorejo Kecamatan Penajam Kabupaten Penajam Paser Utara. Penelitian ini merupakan penelitian deskriptif yang menggambarkan tingkat pengetahuan peternak terhadap limbah peternakan sapi. Responden penelitian ini adalah peternak sapi di Desa Sidorejo tahun 2017 yang berjumlah 31 orang. Metode pengambilan sampel di lokasi penelitian dilakukan dengan proportional random sampling. Data yang diambil berupa data primer dan data sekunder, selanjutnya data yang telah didapatkan kemudian dianalisis menggunakan Skala Likert. Hasil penelitian tingkat pengetahuan peternak terhadap limbah yang dihasilkan sapi masuk dalam kategori rendah 96,77\% dan 3,23\% masuk kedalam kategori sedang.
\end{abstract}

Kata Kunci : Desa Sidorejo, Limbah Peternakan, Pengetahuan peternak

\section{Pendahuluan}

Beberapa dekade terakhir pembangunan sektor peternakan tidak hanya difokuskan pada pemenuhan pangan akan tetapi juga dikaitkan dengan isu kesehatan dan lingkungan. Sementara itu usaha peternakan sapi di Indonesia sebagian besar merupakan usaha peternakan rakyat berskala kecil yang berada pada lingkungan pedesaan dengan penggunaan teknologi yang sederhana (Kasworo et al., 2013). Lebih lanjut dijelaskan Sarwanto (2004) bahwa masih usaha peternakan di Indonesia masih fokus pada produktifitas dan belum mempertimbangan dampak kegiatan peternakan terhadap lingkungan.

Salah satu masalah usaha peternakan yang berkaitan dengan lingkungan adalah limbah yang dihasilkan. Pengolahan limbah yang tidak baik dapat menimbulkan akibat buruk seperti menurunnya kualitas lingkungan, bau yang tidak sedap dan dapat 
menimbulkan gangguan kesehatan pada manusia. Lebih jauh, limbah dalam sekala besar akan berpengaruh terhadap lingkungan global yaitu green house effect.

Kabupaten Penajam Paser Utara merupakan salah satu kabupaten di Kalimantan Timur. Sebagian penduduk kabupaten ini memiliki 1 sampai 3 sapi tiap keluarga yang dipelihara secara ekstensif. Berdasarkan data Dinas Pertanian (2015) jumlah sapi potong dan sapi perah di Kabupaten Penajam Paser Utara berturut-turut yaitu 14.299 ekor dan sapi perah 21 ekor. Berdasarkan penelitian yang dilakukan oleh Budiyanto (2011) diketahui bahwa satu ekor sapi rata-rata setiap hari menghasilkan 7 kilogram kotoran kering. Sehingga dengan asumsi tersebut, maka potensi kotoran sapi kering yang dihasilkan di Kabupaten Penajam Paser Utara, sebanyak 100.240 kilogram per hari. Potensi ini apabila dimanfaatkan dengan baik akan menjadi nilai tambah bagi peternak, lebih jauh lagi, akan mengurangi resiko bahaya pencemaran limbah. Hal inilah yang melatar belakangi dilakukannya penelitian mengenai tingkat pengetahuan peternak sapi terhadap limbah yang dihasilkan di kecamatan Penajam Kabupaten Penajam Paser Utara.

\section{$2 \quad$ Metode Penelitian}

\section{Metode Pengumpulan Data}

Bahan dan alat yang digunakan untuk pengumpulan data dalam penelitian ini adalah alat tulis, kuesioner dan kamera. Data primer diperoleh melalui wawancara langsung yang mendalam terhadap peternak sapi. Data sekunder diperoleh dari dinas atau instansi terkait seperti Kantor Desa/Kelurahan, Balai Penyuluhan Pertanian, Badan Pusat Statistik (BPS) dan instansi pemerintah yang bersangkutan.

\section{Metode Pengambilan Sampel}

(a) Populasi

Populasi atau responden yang digunakan pada penelitian ini di tentukan secara sengaja (purposive) yaitu terdiri dari 5 kelompok tani dengan kriteria 1) tahun terbentuk sebelum tahun 2000 dan 2) jumlah kepememilikan sapi perkelompok minimal 40 ekor . Sedangkan responden yang dipilih yaitu responden dengan kriteria memiliki sapi minimal 3 ekor yang dipelihara baik intensif, semi intensif maupun ekstensif.

(b) Sampel

Pengambilan sampel pada penelitian ini menggunakan teknik penentuan sampel dengan proportional random sampling (Sugiyono, 2013). Untuk menentukan besarnya ukuran sampel dilakukan dengan menggunakan statistik deskriptif berdasarkan rumus Slovin menurut Darmawan (2013) sebagai berikut :

$$
\mathrm{n}=\frac{N}{1+N(e)^{2}}
$$

$\mathrm{n}=$ Jumlah Sampel

$\mathrm{N}$ = Jumlah Populasi 
e = elastisitas $(15 \%)$

Berdasarkan hasil perhitungan yang sudah dilakukan jumlah sampel yang digunakan pada penelitian ini adalah sebanyak 31 peternak sapi. Karena populasi bersifat heterogen yaitu jumlah anggota kelompok tani berbeda-beda, maka teknik pengambilan sampel yang digunakan adalah Proportional Random Sampling yaitu populasi yang terbagi ke dalam sub kelompok dan dari masing-masing sub kelompok diambil sampel. Menurut Sugiono (2013), penentuan jumlah sampel untuk masing-masing sub sektor kelompok tani dihitung secara proporsional dengan menggunakan rumus :

$$
\mathrm{s}=\frac{n}{N} \times S
$$

\section{Keterangan :}

$\mathrm{S} \quad=$ jumlah sampel setiap unit secara proporsional

$\mathrm{S} \quad=$ jumlah seluruh sampel yang didapat

$\mathrm{N} \quad=$ jumlah populasi

$\mathrm{n} \quad=$ jumlah masing-masing unit populasi/kelompok tani.

Tabel 1. Jumlah sampel masing-masing kelompok tani

\begin{tabular}{lllll}
\hline No. & Kelompok Tani & Populasi & $\mathrm{s}=\frac{n}{N} x S$ & Sampel \\
\hline 1. & Sri Rejeki & 18 anggota & $18 / 106 \times 31$ & 5 peternak \\
2. & Dewi Sri & 24 anggota & $24 / 106 \times 31$ & 7 peternak \\
3. & Sri Makmur & 24 anggota & $24 / 106 \times 31$ & 7 peternak \\
4. & Sri Mulih & 20 anggota & $20 / 106 \times 31$ & 6 peternak \\
5. & Sri Dadi & 20 anggota & $20 / 106 \times 31$ & 6 peternak \\
\hline & Jumlah & 106 anggota & & 31 peternak \\
\hline
\end{tabular}

Sumber : BPP Penajam (2016).

(c) Definisi Variabel dan Pengukurannya

Definisi variabel dan pengukuran yang menjadi panduan dalam penelitian ini adalah:

1. Karakteristik limbah adalah faktor yang sangat berperan untuk mendesain system pengolahan secara biologis. Karakteristik limbah peternakan dapat dibagi menjadi tiga kelompok sifat yaitu fisik, kimia dan biologis. (Metode scoring)

2. Manfaat limbah peternakan adalah bagaaimana cara mengkonversi kembali limbah peternakan menjadi produk yang bermanfaat dan memiliki nilai ekonomi yang lebih tinggi. (Metode scoring)

3. Bahaya limbah peternakan adalah masalah yang ditimbulkan akibat pengolahan limbah ternak yang tidak baik dan benar yang dapat menimbulkan polusi lingkungan dan sebagai sumber penyakit bagi manusia maupun hewan. (Metode scoring)

4. Inovasi penanganan limbah adalah suatu usaha penanganan dan pemanfaatan limbah yang dapat mengurangi polusi lingkungan. (metode scoring) 
ISSN 2354-7251 (print)

5. Ketrampilan peternak adalah suatu kemampuan yang dimiliki peternak terhadap suatu hal yang dipertimbangkan sebagai suatu yang penting untuk meunjang keberhasilan dalam mengolah limbah. (metode scoring).

(d) Metode Analisis Data

Analisis data yang akan dilakukan dalam penelitian ini yaitu secara deskriptif, dengan cara membuat tabulasi distribusi responden dari setiap variabel yang diteliti, untuk mendeskripsikan tingkat pengetahuan peternak sapi terhadap limbah yang dihasilkan digunakan skala ordinal yaitu berpedoman pada Skala Likert, dimana setiap jawaban diberi skor (Sugiyono, 2013). Penggunaan skala Likert, maka variabel yang diukur dijabarkan menjadi indikator variabel. Kemudian indikator tersebut dijadikan sebagai titik tolak untuk menyusun item-item instrument yang dapat berupa pernyataan atau pertanyaan.

Setiap pertanyaan diberi skor sesuai dengan pilihan responden, dimana setiap jawaban pertanyaan diberikan skor yang berbeda-beda. Jawaban A atau jawaban yang diinginkan diberi skor 3 , sedangkan jawaban $B$ dan $C$ jawaban yang kurang diinginkan diberi skor 2 dan 1. Skor minimum dan maksimum tingkat pengetahuan peternak dapat dilihat pada Tabel 2.

Tabel 2. Skor Minimum dan Maksimum Tingkat Pengetahuan Peternak

\begin{tabular}{clcc}
\hline No & Tingkat pengetahuan & Skor minimum & Skor maksimum \\
\hline 1. & Karakteristik limbah & 4 & 12 \\
2. & Manfaat limbah & 4 & 12 \\
3. & Bahaya limbah & 5 & 15 \\
4. & Inovasi penanganan limbah & 3 & 9 \\
5. & Ketrampilan peternak & 8 & 24 \\
\hline Jumlah & 24 & 102 \\
\hline
\end{tabular}

Tingkat pengetahuan dibedakan menjadi 3 kelas yaitu: tinggi, sedang dan rendah. Adapun untuk mengetahui interval kelas menurut Suparman (1990) ditentukan dengan rumus sebagai berikut:

$$
\begin{aligned}
& C=\frac{X n-X i}{K} \\
& C=\frac{102-24}{3}=26
\end{aligned}
$$

Keterangan:

$\mathrm{C}=$ interval kelas

$\mathrm{Xn}=$ skor maksimum

$\mathrm{X} \mathrm{i}=$ skor minimum

$\mathrm{K}=$ jumlah kelas

Berdasarkan hasil perhitungan di atas, tingkat pengetahuan peternak terhadap pengelolaan limbah dapat dilihat pada Tabel 3 
Table 3. Interval kelas tingkat pengetahuan peternak

\begin{tabular}{ccc}
\hline No & Interval Kelas & Tingkat Pengetahuan \\
\hline 1. & $24,00-50,00$ & Rendah \\
2. & $50,01-76,01$ & Sedang \\
3. & $76,02-102,02$ & Tinggi \\
\hline
\end{tabular}

Sumber : Data diolah, 2017

\section{Hasil dan Pembahasan}

\section{Keadaan Umum Lokasi Penelitian}

(a) Letak Geografis

Desa Sidorejo merupakan hasil pemekaran dari Kelurahan Petung dan salah satu dari Desa/Kelurahan dari 23 Desa/Kelurahan yang berada di Kecamatan Penajam Kabupaten Penajam Paser Utara. Wilayah geografis Desa Sidorejo berbatasan dengan 4 (empat) Desa/Kelurahan lainnya, yaitu:

$\begin{array}{ll}\text { Sebelah utara } & \text { : Berbatasan dengan Kelurahan Petung } \\ \text { Sebelah Selatan } & \text { : Berbatasan dengan Kelurahan Tanjung Tengah } \\ \text { Sebelah Timur } & \text { : Berbatasan dengan Desa Girimukti dan Kelurahan Saloloang } \\ \text { Sebelah Barat } & \text { : Berbatasan dengan Kelurahan Petung. }\end{array}$

(b) Luas Wilayah

Luas wilayah yang dimiliki suatu daerah adalah salah satu faktor yang menentukan produktifitas perekonomian wilayah tersebut. Tersedianya lahan yang luas dan didukung dengan kondisi tanah yang subur merupakan salah satu pendukung dalan peningkatan dan pengembangan di bidang pertanian, perkebunan dan peternakan. Luas wilayah yang dimiliki Desa Sidorejo seluas 8,96 $\mathrm{Km}^{2}$ atau 0,73\% dari luas wilayah Kecamatan Penajam seluas 1230,44 Km² (Kecamatan Penajam dalam angka, 2016).

(c) Kependudukan

Penduduk mempunyai peran yang sangat penting dalam perkembangan suatu daerah. Kepadatan penduduk dalam suatu tempat yang kemudian diimbangi dengan tingginya kualitas sumber daya dalam berbagai bidang akan mempercepat kemajuan suatu daerah dan sebaliknya, begitupun di Desa Sidorejo. Oleh sebab itu peningkatan kualitas sumber daya manusia dalam suatu wilayah akan sangat penting agar dapat meningkatkan persaingan dalam pembangunan suatu daerah. Adapun kondisi keadaan penduduk di Desa Sidorejo berdasarkan jenis kelamin dapat dilihat pada Tabel 4.

Tabel 4. Keadaan Penduduk Berdasarkan Jenis kelamin

\begin{tabular}{cccc}
\hline No. & Jenis Kelamin & Jumlah (Jiwa) & Presentase (\%) \\
\hline 1. & Laki-laki & 1072 & 51,61 \\
2. & Perempuan & 1005 & 48,39 \\
\hline & Total & 2077 & 100 \\
\hline
\end{tabular}

Sumber : Kecamatan Penajam dalam angka (2016) 
Pada Tabel 4, dapat diketahui bahwa Jumlah penduduk di Desa Sidorejo pada tahun 2016 adalah 2.077 jiwa, adapun penduduk yang berjenis kelamin perempuan hampir sebanding dengan penduduk yang berjenis kelamin laki-laki yaitu 1072 jiwa : 1005 jiwa atau $51,61 \%$ : 48,39\%. Jumlah penduduk tersebut merupakan salah satu faktor pendukung dalam pengembangan subsektor peternakan sebagai sumber tenaga kerja.

(d) Mata Pencaharian

Jenis pekerjaan atau mata pencaharian yang ditekuni oleh penduduk di Desa Sidorejo dapat dilihat pada Tabel 5.

Tabel 5. Keadaan penduduk berdasarkan mata pencaharian

\begin{tabular}{cccc}
\hline No. & Jenis Pekerjaan & Jumlah (Jiwa) & Persentase (\%) \\
\hline 1. & Petani / peternak & 625 & 83,89 \\
2. & Buruh tani & 36 & 4,83 \\
3. & Pegawai Negeri Sipil (PNS) & 47 & 6,31 \\
4. & Nelayan & 3 & 0,40 \\
5. & TNI/POLRI & 12 & 1,61 \\
6. & Buruh Harian Lepas (BHL) & 22 & 2,95 \\
\hline
\end{tabular}

Sumber : Kecamatan Penajam dalam angka (2016)

Berdasarkan Tabel 5, dapat diketahui bahwa sekita 745 orang yang memilih profesi sebagai petani/peternak dan profesi ini yang paling banyak digeluti oleh masyarakat di Desa Sidorejo Kecamatan Penajam, sedangkan profesi yang paling sedikit digeluti oleh masyarakat adalah sebagai nelayan dengan jumlah hanya 3 orang. Hal ini disebabkan karena banyaknya penggunaan lahan dibidang pertanian dan peternakan sehingga membuat masyarakat memilih pekerjaan sebagai petani ataupun peternak.

(e) Keadaan Peternakan

Jenis dan populasi ternak yang terdapat di Desa Sidorejo Kecamatan Penajam disajikan dalam Tabel 6.

Tabel 6. Jenis dan Populasi Ternak di Desa Sidorejo

\begin{tabular}{cccc}
\hline No. & Jenis Ternak & Jumlah (ekor) & Persentase (\%) \\
\hline 1. & Sapi & 495 & 17,82 \\
2. & Ayam & 1976 & 71,16 \\
3. & Kambing & 72 & 2,59 \\
4. & Itik & 234 & 8,43 \\
\hline & Total & 2777 & 100 \\
\hline
\end{tabular}

Sumber : Kecamatan Penajam dalam angka (2016)

Berdasarkan Tabel 6 dapat diketahui jenis ternak yang paling banyak dipelihara oleh masyarakat di Desa Sidorejo adalah ternak ayam dengan populasi sebanyak 1976 ekor $(71,16 \%)$. Sedangkan ternak sapi yang dipelihara oleh masyarakat di Desa Sidirejo lebih sedikit dari ternak ayam yaitu sebanyak 495 ekor (17,82\%). Hal ini dikarenakan waktu dan tenaga yang dikeluarkan untuk memelihara sapi lebih banyak dari pada ayam, sehingga masyarakat lebih memilih ayam.

\section{Keadaan Umum Responden}

(a) Umur, pendidikan dan Pendapatan Responden 
Berdasarkan penelitian yang sudah dilakukan diperoleh data umur, pendidikan dan pendapatan responden dapat dilihat pada Tabel 7 berikut.

Tabel 7. Klasifikasi Responden Berdasarkan Umur, pendidikan dan pendapatan

\begin{tabular}{cccccccccc}
\hline \hline No. & $\begin{array}{c}\text { Umur } \\
\text { (Tahun) }\end{array}$ & $\begin{array}{c}\text { Jumlah } \\
\text { (Jiwa) }\end{array}$ & $\%$ & Pendidikan & $\begin{array}{c}\text { Jumlah } \\
\text { (Jiwa) }\end{array}$ & $\%$ & $\begin{array}{c}\text { Pendapatan } \\
\text { (Juta Rupiah) }\end{array}$ & $\begin{array}{c}\text { Jumlah } \\
\text { (Jiwa) }\end{array}$ & $\%$ \\
\hline 1. & $29-37$ & 3 & 9,68 & SD & 19 & 61,32 & $<1$ & 8 & 25,81 \\
2. & $38-46$ & 2 & 6,45 & SMP & 10 & 32,26 & $1-2$ & 22 & 70,97 \\
3. & $47-56$ & 15 & 48,38 & SMA & 1 & 3,26 & $>2$ & 1 & 3,23 \\
4. & $57-65$ & 11 & 32,26 & S1 & 1 & 3,26 & - & - & - \\
\cline { 2 - 10 } & Sumber : Data Primer (diolah), 2017. & & & & & &
\end{tabular}

Sumber : Data Primer (diolah), 2017.

Menurut Suartha (2011) golongan umur 15-64 tahun tergolong usia produktif. Berdasarkan hal tersebut maka sebanyak 30 responden (96,77\%) termasuk dalam usia produktif. Karakteristik umur responden yang paling banyak adalah pada kelompok umur 47-56 tahun sebanyak 48,38\%. Sedangkan yang paling sedikit adalah responden yang berumur 38-46 tahun sebanyak 6,45\%. Ditinjau dari segi pendidikan, sebanyak 19 responden $(61,32 \%)$ responden berpendidikan Sekolah Dasar (SD) dan rata-rata pendapatan responden dalam satu bulan yaitu berkisar antara 1 juta sampai dengan 2 juta rupiah $(70,97 \%)$.

(b) Kepemilikan Ternak dan Pengalaman Beternak

Keadaan umum responden ditinjau dari kepemilikan ternak dan pengalaman beternak dapat dilihat pada Tabel 10.

Tabel 10. Klasifikasi Responden Berdasarkan Kepemilikan Ternak dan Pengalaman Beternak

\begin{tabular}{ccccccc}
\hline \hline No. & $\begin{array}{c}\text { Kepemilikan } \\
\text { Ternak (Sapi) }\end{array}$ & $\begin{array}{c}\text { Jumlah } \\
\text { (Jiwa) }\end{array}$ & $\%$ & $\begin{array}{c}\text { Pengalaman } \\
\text { Beternak } \\
\text { (Tahun) }\end{array}$ & $\begin{array}{c}\text { Jumlah } \\
\text { (Jiwa) }\end{array}$ & $\%$ \\
\hline 1. & $3-5$ (ekor) & 8 & 25,81 & $<10$ & 7 & 22,58 \\
2. & $6-8$ (ekor) & 21 & 67,74 & $10-20$ & 22 & 70,97 \\
3. & $9-11$ (ekor) & 1 & 3,23 & $>20$ & 2 & 6,45 \\
4 & $12-15$ (ekor) & 1 & 3,23 & - & - & - \\
\hline
\end{tabular}

Sumber : data Primer (diolah), 2017

Keadaan umum responden ditinjau dari kepemilikan ternak dan pengalaman beternak menunjukkan bahwa sebagian besar responden memiliki ternak yang cukup banyak dan pengalaman beternak yang cukup lama, berturut-turut yaitu 6-8 ekor ternak dan pengalaman beternak pada kisaran 10 sampai dengan 20 tahun.

\section{Tingkat Pengetahuan Peternak Terhadap Limbah yang Dihasilkan Sapi}

(a) Karakteristik Limbah

Distribusi interval kelas indikator karakteristik limbah dapat dilihat dalam Tabel 13.

Tabel 13. Distribusi Interval Kelas Indikator Karakteristik limbah

\begin{tabular}{|c|c|c|c|c|}
\hline No. & Interval Kelas & $\begin{array}{c}\text { Tingkat } \\
\text { Pengetahuan }\end{array}$ & $\begin{array}{c}\text { Jumlah Responden } \\
\text { (Jiwa) }\end{array}$ & Persentase (\%) \\
\hline 1. & $4,00-6,66$ & Rendah & 1 & 3,23 \\
\hline 2. & $6,67-9,35$ & Sedang & 30 & 96,77 \\
\hline 3. & $9,36-12,02$ & Tinggi & 0 & 0 \\
\hline $\mathrm{T}$ & $\begin{array}{l}\text { Total } \\
\text { kor dan rata-rata } \\
\text { Kategori }\end{array}$ & & $\begin{array}{c}31 \\
227(7,32) \\
\text { Sedang }\end{array}$ & 100 \\
\hline
\end{tabular}


Berdasarkan data yang diperoleh dari hasil penelitian tentang tingkat pengetahuan peternak terhadap limbah yang dihasilkan sapi ditinjau dari karakteristik limbah menunjukkan kategori sedang, hal ini terlihat dari skor yang diperoleh sebanyak 227 dengan rata-rata 7,32\%. Dari 31 responden didapatkan bahwa sebagian besar yaitu 30 responden $(96,77 \%)$ termasuk dalam kategori sedang sedangkan, Sebagian kecil responden yaitu 1 responden (3,23\%) termasuk dalam kategori rendah dan tidak ada responden yang masuk dalam kategori tinggi. Sutjipta (2005) dalam Suartha (2011) menyatakan pengetahuan merupakan kemampuan mengingat kembali informasi yang telah diterima sebelumnya seperti fakta, terminologi, rumus, cara pemecahan masalah dan sebagainya. Kemampuan mengingat ini hanya terbatas pada mengucapkan kembali katakata yang sama atau persis, hafal dan ingat, tetapi belum mengerti maksudnya.

Benar yang dinyatakan Sutjipta (2005) dalam Suartha (2011), dalam hal ini responden hanya mengetahui informasi tentang karakteristik limbah, seperti jenis limbah yang dihasikan ternak yaitu feses dan urine, limbah padat berupa feses dan limbah cair berupa urine tetapi belum mengerti maksunya hanya hafal dan ingat tentang beberapa karakteristik limbah. Kurangnya pengetahuan, rasa ingin tahu tentang limbah yang dihasilkan sapi dan tidak adanya penyuluhan khusus tentang limbah ternak di desa tersebut yang membuat tingkat pengetahuan peternak di tinjau dari karakteristik limbah di Desa Sidorejo masuk dalam kategori sedang.

(b) Manfaat Limbah

Distribusi interval kelas indikator manfaat limbah dapat dilihat dala Tabel 14.

Tabel 14. Distribusi Interval Kelas Indikator Manfaat Limbah

\begin{tabular}{ccccc}
\hline No. & Interval Kelas & $\begin{array}{c}\text { Tingkat } \\
\text { Pengetahuan }\end{array}$ & $\begin{array}{c}\text { Jumlah Responden } \\
(\text { Jlwa })\end{array}$ & Persentase (\%) \\
\hline 1. & $4,00-6,70$ & Rendah & 5 & 16.13 \\
2. & $6,68-9,35$ & Sedang & 26 & 83,87 \\
3. & $9,36-12,02$ & Tinggi & 0 & 0 \\
\hline \multicolumn{5}{r}{ Total skor dan rata-rata } \\
Kategori & & 31 & 100 \\
& & & $216(6,97)$ & \\
\hline
\end{tabular}

Sumber : Data Primer (diolah), 2017.

Indikator manfaat limbah di Desa Sidorejo Kecamatan Penajam mendapatkan total skor tingkat pengetahuan responden sebanyak 216 dan rata-rata skor 6,79 adalah termasuk kedalam kategori sedang. Sebagian besar responden yaitu sebanyak 26 orang $(83,87 \%)$ mempunyai tingkat pengetahuan dengan kategori sedang, 5 orang $(16,31 \%)$ mempunyai tingkat pengetahuan yang rendah dan tidak ada yang memiliki pengetahuan tinggi.

Berdasarkan data yang diperoleh dari hasil penelitian tentang tingkat pengetahuan peternak terhadap limbah yang dihasilkan sapi ditinjau dari manfaat limbah menunjukkan kategori sedang, hal ini terlihat dari skor yang diperoleh sebanyak 216 dengan rata-rata $6,97 \%$. Dari 31 responden didapatkan bahwa sebagian besar yaitu 26 responden $(83,87 \%)$ 
termasuk dalam kategori sedang sedangkan, Sebagian kecil responden yaitu 5 responden $(16,13 \%)$ termasuk dalam kategori rendah dan tidak ada responden yang masuk dalam kategori tinggi.

Pada dasarnya responden tidak mengetahui beberapa cara mengolah limbah seperti cara membuat biogas, pupuk cair dan bio arang. Responden juga berfikir untuk mengolah limbah memerlukan biaya cukup mahal dan cara pembuatannya yang membutuhkan waktu yang cukup lama sehingga responden tidak merasakan adanya manfaat tambahan pendapatan ataupun keuntungan lain dengan adanya limbah sapi ini karena belum dicoba untuk membuat. Padahal apabila dimanfaatkan dengan baik untuk dikelolala menjadi biogas, akan dapat mengurangi gas metana $(\mathrm{CH} 4)$ yang dikeluarkan dari limbah feses karena digunakan sebagai bahan bakar (Rahayu et al. 2009).

Dalam hal ini sebagian besar responden hanya mengetahui jika limbah ternak sapi dapat dimanfaatkan menjadi pupuk organik, pupuk cair dan biogas dan tidak mengetahui jika limbah ternak dapat dimanfaatkn menjadi bio arang. Rata-rata responden paling banyak mengetahui manfaat pupuk organik dari pada manfaat dari biogas dan pupuk cair hampir rata-rata semua responden tidak mengetahui tidak mengetahui jika limbah dapat dimanfaatkan juga menjadi bio arang. Responden juga hanya mengetahui manfaat biogas seperti untuk memasak, pupuk organik untuk memupuk tanaman dan menyuburkan tanah serta tidak mengetahui manfaat dari bio arang. Hal inilah yang menyebabkan tingkat pengetahuan peternak ditinjau dari manfaat limbah masuk dalam kategori sedang.

(c) Bahaya Limbah

Distribusi interval kelas indikator bahaya limbah dapat dilihat dala Tabel 15.

Tabel 15. Distribusi Interval Kelas Indikator Bahaya Limbah

\begin{tabular}{ccccc}
\hline No. & Interval Kelas & $\begin{array}{c}\text { Tingkat } \\
\text { Pengetahuan }\end{array}$ & $\begin{array}{c}\text { Jumlah Responden } \\
(\text { Jiwa })\end{array}$ & Persentase (\%) \\
\hline 1. & $5,00-8,33$ & Rendah & 22 & 76,74 \\
2. & $8,34-11,67$ & Sedang & 9 & 29,03 \\
3. & $11,68-15,01$ & Tinggi & 1 & 3,23 \\
\hline \multicolumn{5}{r}{ Total skor dan rata-rata } \\
Kategori & & 31 & 100 \\
& Total & $235(7,55)$ & \\
\hline
\end{tabular}

Sumber : Data Primer (diolah), 2017.

Indikator bahaya limbah di Desa Sidorejo Kecamatan Penajam mendapatkan total skor tingkat pengetahuan responden sebanyak 235 dengan rata-rata skor 7,55 adalah temasuk kedalam kategori rendah. Sebagian besar responden yaitu sebanyak 21 orang $(67,74 \%)$ mempunyai tingkat pengetahuan rendah, 9 orang $(29,03 \%)$ mempungyai tingkat pengetahuan sedang dan 1 orang $(3,23 \%)$ yang mempunyai tingkat pengetahuan tinggi.

Berdasarkan data yang diperoleh dari hasil penelitian tentang tingkat pengetahuan peternak terhadap limbah yang dihasilkan sapi ditinjau dari bahaya limbah menunjukkan kategori rendah, hal ini terlihat dari skor yang diperoleh sebanyak 234 dengan rata-rata $7,55 \%$. Dari 31 responden didapatkan bahwa sebagian besar yaitu 21 responden $(67,74 \%)$ 
termasuk dalam kategori rendah. Masih banyak responden yang belum mengetahui tentang bahaya limbah peternakan karena menurut para responden, mereka tidak merasakan dampak negatif dari limbah ternak tersebut karena sudah terbiasa. Sebanyak 9 responden $(29,03 \%)$ termasuk dalam kategori sedang. Dalam hal ini responden hanya mengetahui beberapa bahaya yang ditimbulkan dari limbah ternak namun tidak mengetahui semua bahaya yang ditimbulkan dari limbah ternak, sehingga mereka menganggap bahwa limbah tersebut tidak terlalu membahayakan bagi lingkungan disekitar maupun bagi kesehatan manusia . terdapat 1 responden $(3,23 \%)$ saja yang masuk dalam kategori tinggi. Responden yang masuk kedalam kategori tinggi mengetahui bahaya limbah jika dibiarkan begitu saja dapat menyebabkan mencemari lingkungan, menimbulkan penyakit dan mencemari air tanah sehingga responden tersebut mengolah limbah ternaknya dengan baik dan benar. Responden sebagian besar tidak dapat menjawab dengan detail bahaya limbah yang berkaitan dengan green house effect dan dampak dampak lainnya. Seperti yang dijabarkan oleh (Rachmawati, 2000) bahwa beberapa gas yang dihasilkan dari limbah ternak antara lain ammonium, hydrogen sulfide, $\mathrm{CO} 2$ dan $\mathrm{CH} 4$ yang dapat menimbulkan gas efek rumah kaca (Green House Gas) dan menimbulkan bau tak sedap dan mengganggu kesehatan manusia.

(d) Ketrampilan

Distribusi interval kelas indikator ketrampilan dapat dilihat dalam Tabel 16.

Tabel 16. Distribusi Interval Kelas Indikator ketrampilan

\begin{tabular}{ccccc}
\hline No. & Interval Kelas & $\begin{array}{c}\text { Tingkat } \\
\text { Pengetahuan }\end{array}$ & $\begin{array}{c}\text { Jumlah Responden } \\
(\text { Jiwa) }\end{array}$ & Persentase (\%) \\
\hline 1. & $8,00-13,33$ & Rendah & 20 & 64,52 \\
2. & $13,34-18,76$ & Sedang & 11 & 35,48 \\
3. & $18.68-24,01$ & Tinggi & 0 & 0 \\
\hline \multicolumn{5}{r}{ Total skor dan rata-rata } \\
Kategori & & 31 & 100 \\
& & $393(12,68)$ & \\
\hline
\end{tabular}

Sumber : Data Primer (diolah), 2017.

Indikator ketrampilan di Desa Sidorejo Kecamatan Penajam mendapatkan total skor tingkat pengetahuan responden sebanyak 393 dengan rata-rata skor 12,68 adalah temasuk kedalam kategori rendah. Sebagian besar responden yaitu sebanyak 20 orang (64,52\%) mempunyai ketrampilan yang rendah, 11 orang $(35,48 \%)$ mempunyai ketrampilan sedang dan tidak ada yang mempunyai ketrampilan tinggi.

Berdasarkan data yang diperoleh dari hasil penelitian tentang tingkat pengetahuan peternak terhadap limbah yang dihasilkan sapi ditinjau dari ketrampilan peternak menunjukkan kategori rendah, hal ini terlihat dari skor yang diperoleh sebanyak 393 dengan rata-rata 12,68\%. Dari 31 responden didapatkan bahwa sebagian besar yaitu 20 responden $(64,52 \%)$ termasuk dalam kategori rendah. Sebagian besar peternak tidak melakukan terhadap limbah yang dihasilkan, peternak membiarkan begitu saja limbah ternaknya tanpa ada pengolahan. Sebagian besar peternak yang tidak mengolah limbah karena tidak 
memiliki keahlian maupun pengetahuan untuk mengolah limbah ternaknya. Ada juga yang tidak mau mengolah limbah karena merasa sudah lelah dari sawah kemudian pulang mencari rumput untuk pakan ternak sehingga tidak ada waktu untuk mengolah limbah ternaknya Ada juga yang tidak mengolah limbah karena tidak memiliki biaya untuk membeli bahan campuran untuk mengolah limbah.

Sebagian kecil responden yaitu 11 responden (35,48\%) termasuk dalam kategori sedang. Berdasarkan hasil penelitian yang didapatkan kebanyakan responden menguasai cara mengolah limbah ternak menjadi pupuk organik dari pada mengolah limbah ternak menjadi pupuk cair, biogas maupun bio arang. Ada beberapa responden yang sering mengolah limbah ternak ada juga yang kadang - kadang baru mengelolah limbah ternaknya. Salah satu faktor yang membuat responden jarang mengolah limbah ternaknya yaitu waktu dan tenaga. Mengapa demikian, karena para responden mayoritas adalah petani padi sehingga beternak hanya dijadikan sebagai sampingan. Disaat ada waktu luang ataupun tidak lelah barulah mengolah limbah, jika tidak ada waktu limbah dibiarkan begitu saja.

(e) Inovasi Penanganan Limbah

Inovasi adalah gagasan, tindakan atau barang yang dianggap baru oleh seseorang. Kebaruan inovasi itu diukur secara subyektif, menurut pandangan individu yang menangkapnya. Proses adopsi itu terjadi mulai seseorang mendengar suatu ide baru sampai akhirnya melaksanakannya (mengadopsinya) (Mulatmi et al. 2016). Distribusi interval kelas indikator inovasi penangan limbah dapat dilihat dalam Tabel 17.

Tabel 17. Distribusi Interval Kelas Indikator Inovasi Penanganan Limbah

\begin{tabular}{|c|c|c|c|c|}
\hline No. & Interval Kelas & $\begin{array}{c}\text { Tingkat } \\
\text { Pengetahuan }\end{array}$ & $\begin{array}{c}\text { Jumlah Responden } \\
\text { (Jiwa) }\end{array}$ & Persentase (\%) \\
\hline 1. & $3,00-5,00$ & Rendah & 25 & 80,65 \\
\hline 2. & $5,01-7,01$ & Sedang & 4 & 12,90 \\
\hline 3. & $7,02-9,07$ & Tinggi & 2 & 6,45 \\
\hline $\mathrm{T}$ & $\begin{array}{l}\text { Total } \\
\text { or dan rata-rata } \\
\text { kategori }\end{array}$ & & $\begin{array}{c}31 \\
144(4,64) \\
\text { Rendah }\end{array}$ & 100 \\
\hline
\end{tabular}

Sumber: Data Primer (diolah), 2017.

Indikator inovasi penanganan limbah di Desa Sidorejo Kecamatan Penajam mendapatkan total skor tingkat pengetahuan responden sebanyak 144 dengan rata-rata skor 4,64 adalah temasuk kedalam kategori rendah. Sebagian besar responden yaitu sebanyak 25 orang $(80,65 \%)$ mempunyai tingkat pengetahuan rendah, 4 orang $(12,90 \%)$ mempungyai tingkat pengetahuan sedang dan 2 orang $(6,45 \%)$ yang mempunyai tingkat pengetahuan tinggi.

Berdasarkan data yang diperoleh dari hasil penelitian tentang tingkat pengetahuan peternak terhadap limbah yang dihasilkan sapi ditinjau dari inovasi penanganan limbah menunjukkan kategori rendah, hal ini terlihat dari skor yang diperoleh sebanyak 393 dengan 
rata-rata 12,68\%. Dari 31 responden didapatkan sebanyak 25 responden (80,65\%) masuk dalam kategori rendah. Hal ini disebabkan karena kurangnya pengetahuan responden tentang inovasi penanganan limbah dan cara penanganan limbah ternak yang baik dan benar. Sebanyak 4 responden (12,90\%) masuk dalam kategori sedang.hal ini menandakan bahwa responden mengetahui inovasi penanganan limbah dan cara mengelolah limbah yang baik dan benar.

(f) Tingkat Pengetahuan Terhadap Limbah yang Dihasilkan Sapi

Distribusi interval kelas tingkat pengetahuan peternak terhadap limbah sapi yang dihasilkan dapat dilihat pada Tabel 18.

Tabel 18. Distribusi Interval Kelas Tingkat Pengetahuan Peternak

\begin{tabular}{ccccc}
\hline No. & Interval Kelas & $\begin{array}{c}\text { Tingkat } \\
\text { Pengetahuan }\end{array}$ & $\begin{array}{c}\text { Jumlah Responden } \\
\text { (Jiwa) }\end{array}$ & Persentase (\%) \\
\hline 1. & $24,00-50,00$ & Rendah & 30 & 96,77 \\
2. & $50,01-76,01$ & Sedang & 1 & 3,23 \\
3. & $76,02-102,02$ & Tinggi & 0 & 0 \\
\hline \multicolumn{7}{r}{ Total skor dan rata-rata } & & 31 & 100 \\
& Kategori & & $1214(39,16)$ & \\
\hline
\end{tabular}

Sumber : Data Primer (diolah), 2017.

Berdasarkan hasil penelitian tingkat pengetahuan peternak terhadap limbah yang dihasilkan sapi di Desa Sidorejo Kecamatan Penajam Kabupaten Penajam Paser Utara ditinjau dari indikator pengetahuan mengenai bahaya limbah, keterampilan dalam pengolahan limbah dan inovasi penanganan limbah diketahui masih berada dalam kategori rendah. Sedangkan dua indikator yang lain yaitu karakteristik limbah dan manfaat limbah berada dalam kategori sedang, sehingga secara keseluruhan, tingkat pengetahuan peternak mengenai limbah berada dalam kategori rendah dengan skor rata-rata 39,16. Beberapa hal yang kemungkinan menjadi faktor penyebab adalah karakteristik peternak khususnya tingkat pendidikan yang tidak optimal untuk meningkatkan pengetahuan terkait dengan penanganan limbah. Mardikanto (1993) bahwa pendidikan akan Berhubungan terhadap tingkat pengetahuan dan keterampilan petani peternak, dimana petani peternak akan berusaha untuk memanfaatkan setiap kesempatan yang dapat memajukan usahataninya. Selain itu, minimalnya nilai ekonomi yang diperoleh dari limbah juga menjadi faktor penghambat peternak untuk menggali informasi terkait limbah. Profesi petani dan peternak merupakan profesi dominan pada wilayah penelitian (83\%). Keberadaan petani peternak yang banyak menyebabkan komoditas limbah bukanlah sebuah kebutuhan yang harus dipenuhi dari luar rumah tangga masing-masing petani, sehingga pemasaran limbah dalam bentuk pupuk atau produk yang lain cukup sulit untuk dilakukan. Salah satu faktor penyebab yang terakhir adalah kurangnya penyuluhan dan pelatihan teantang pengolahan limbah. Berdasarkan informasi yang diperoleh dari masyarakat, pelatihan dilakukan 1 
sampai dengan 2 kali setiap tahun dan biasanya hanya dihadiri oleh perwakilan peternak.

(Schreinemachers et al., 2016)

\section{Kesimpulan}

Berdasarkan hasil penelitian tersebut maka dapat disimpulkan bahwa tingkat pengetahuan peternak terhadap limbah yang dihasilkan sapi termasuk kedalam kategori rendah $(96,77 \%)$ ditinjau dari lima indikator yaitu karakteristik limbah, bahaya limbah, manfaat limbah, keterampilan dan inovasi pengolahan limbah.

\section{Daftar Pustaka}

BPS Penajam Paser Utara. (2017). Kecamatan Penajam Dalam Angka 2016. Badan Pusat Statistik, Penajam Paser Utara. Diakses 5 November 2018 dari https://ppukab.bps.go.id/

Budiyanto, M.A.K.,. (2013). Tipologi pendayagunaan kotoran sapi dalam upaya mendukung pertanian organik di Desa Sumbersari Kecamatan Poncokusumo Kabupaten Malang. Jurnal Gamma, 7(1).

Darmawan. (2013). Metode Penelitian Kuantitatif. Bandung: Remaja Rosdakarya.

Dinas Pertanian Paser. (2015). Data Populasi Ternak Tahun 2014. Penajam Paser Utara.

Rachmawati. (2000). Upaya pengelolaan lingkungan usaha peternakan ayam. Wartazoa. $9(2): 73-80$.

Rahayu, S., Purwaningsih, D., dan Pujiyanto. (2009). Pemanfaatan kotoran ternak sapi sebagai sumber energi alternatif ramah lingkungan beserta aspek sosial kulturnya. Inotek. Vol 13 (2).

Kasworo, A., Izzati, M., dan Kismartini. (2013). Daur Ulang Kotoran ternak Sebagai Upaya Mendukung Peternakan Sapi Potong Yang Berkelanjutan di Desa Jogonayan Kecamatan Ngablak Kabupaten Magelang. Prosiding Seminar Nasional Pengelolaan Sumberdaya Alam dan Lingkungan. Semarang, 10 September 2013

Mardikanto, T. (1993). Penyuluhan Pembangunan Pertanian. Sebelas Maret University Press. Surakarta

Mulatmi, S. N. W., B. Guntoro, B. P. Widyobroto, S. Nurtini, dan A. Pertiwiningrum. (2016). Strategi Peningkatan Adopsi Inovasi pada Peternakan Sapi Perah Rakyat di Daerah Istimewa Yogyakarta, Jawa Tengah, dan Jawa Timur. Buletin Peternakan. 40 (3) :219-227

Schreinemachers, P., Wu, M. huey, Uddin, M. N., Ahmad, S., \& Hanson, P. (2016). Farmer training in off-season vegetables: Effects on income and pesticide use in Bangladesh. Food Policy, 61, 132-140. https://doi.org/10.1016/j.foodpol.2016.03.002

Sarwanto, Doso. (2004). Model Pencemaran Limbah Peternakan sapi Perah Rakyat pada Beberapa Kondisi Fisik Alami dan Sosial Ekonomi (Studi Kasus di Provinsi Jawa Tengah). Disertasi. Sekolah Pascasarjana Institut Pertanian Bogor. Bogor.

Suartha, I.D.G. (2011). Studi Korelasi Tingkat Pengetahuan Dengan Sikap Petani Tentang Pengendalian Hama Terpadu (PHT) (Kasusi di Kecamatan Narmada kabupaten Lombok Barat). Ganec Swara. Vol 5 (2). 
Sugiyono. (2013). Statistika untuk Penelitian. Cetakan Keenam. Penerbit Alfabeta. Bandung.

Sumartono, F. (2011). Hubungan Antara Tingkat Perhatian Dengan Tingkat Pengetahuan Mahasiswa Universitas Bina Nusantara Pada Majalah Lentera Ycab. Komunikologi. Vol 8 (1)

Suparman, I.A. (1990). Statistika sosial. Rajawali Pers, Jakarta 